\title{
Effect of protein restriction on the messenger RNA contents of bone-matrix proteins, insulin-like growth factors and insulin-like growth factor binding proteins in femur of ovariectomized rats
}

\author{
BY YUSUKE HIGASHI, ASAKO TAKENAKA, SHIN-ICHIRO TAKAHASHI \\ AND TADASHI NOGUCHI* \\ Laboratory of Nutritional Biochemistry, Department of Applied Biological Chemistry, Division of \\ Agriculture and Life Sciences, University of Tokyo, Bunkyo-ku, Tokyo 113, Japan
}

(Received 12 December 1994 - Revised 10 August 1995 - Accepted 12 October 1995)

It has been reported that loss of ovarian oestrogen after menopause or by ovariectomy causes osteoporosis. In order to elucidate the effect of dietary protein restriction on bone metabolism after ovariectomy, we fed ovariectomized young female rats on a casein-based diet $(50 \mathrm{~g} / \mathrm{kg}$ diet (protein restriction) or $200 \mathrm{~g} / \mathrm{kg}$ diet (control)) for 3 weeks and measured mRNA contents of bone-matrix proteins such as osteocalcin, osteopontin and $\alpha 1$ type I collagen, insulin-like growth factors (IGF) and IGF-binding proteins (IGFBP) in femur. Ovariectomy decreased the weight of fat-free dry bone and increased urinary excretion of pyridinium cross-links significantly, although dietary protein restriction did not affect them. Neither ovariectomy nor protein restriction affected the content of mRNA of osteopontin and osteocalcin; however, ovariectomy increased and protein restriction extensively decreased the $\alpha 1$ type I collagen mRNA content in bone tissues. Ovariectomy increased IGF-I mRNA only in the rats fed on the control diet. Conversely, protein restriction increased and ovariectomy decreased the IGF-II mRNA content in femur. Furthermore, the contents of IGFBP-2, IGFBP-4 and IGFBP-5 mRNA increased, but the content of IGFBP-3 mRNA decreased in femur of the rats fed on the protein-restricted diet. In particular, ovariectomy decreased the IGFBP-2 mRNA content in the protein-restricted rats and the IGFBP- 6 mRNA content in the rats fed on the control diet. These results clearly show that the mRNA for some of the proteins which have been shown to be involved in bone formation are regulated by both quantity of dietary proteins and ovarian hormones.

Bone: Insulin-like growth factor: Ovariectomy: Osteoporosis

Osteoporosis is a serious disease worldwide. Among many types of this disease, postmenopausal osteoporosis is observed frequently. Decreased plasma oestrogen concentration is believed to be its principal cause (Christiansen et al. 1982; Gallagher, 1990). Accordingly, ovariectomized animals have been used as a suitable model to study osteoporosis, because loss of ovarian oestrogen by ovariectomy causes a similar situation to menopause (Kalu, 1991). In general, rapid decreases in bone mass have been observed in ovariectomized rats (Wronski et al. 1985; Kalu et al. 1989). This decrease in bone mass is known as osteopenia which has been shown to be caused by raised bone turnover, due to increased bone resorption and the concomitant increase in bone formation (Wronski et al. 1986; Ismail et al. 1988); the raised bone turnover is depressed by oestrogen (Wronski et al. 1988a; Kalu et al. 1991). It is well known that bone resorption is performed by osteoclasts and bone formation by osteoblasts. Therefore, osteopenia is thought to be the result of the much increased activity of osteoclasts and less enhanced activity of osteoblasts by lack of ovarian oestrogen.

\footnotetext{
* For reprints.
} 
Turner et al. (1990) reported that expression of osteocalcin, osteonectin, osteopontin and $\alpha 1$ chain of type I collagen genes in periosteal osteoblasts of ovariectomized rats were down-regulated by treatment of the animals with diethylstilboestrol. This means that oestrogens regulate the gene expression of these proteins which have been presumed to play important roles in bone formation. Furthermore, some growth factors and cytokines were reported to be involved in regulation of bone metabolism (Manolagas \& Jilka, 1992; Baylink et al. 1993; Canalis et al. 1993; Horowitz 1993). In particular, insulin-like growth factors (IGF) and their binding proteins (IGFBP), which could modulate IGF's actions, might play important roles in bone formation (Nilsson et al. 1994; Rosen et al. 1994). Finally dietary factors have been shown to be important in bone and $\mathrm{Ca}$ metabolism (LeRoith \& Pimstone, 1973); however, the effect of dietary conditions on the changes in mRNA of bone-matrix proteins and some growth factors in bones has not been studied.

The present study was undertaken to investigate the effects of protein restriction on changes in the mRNA contents of osteopontin, osteocalcin, $\alpha 1$ type I collagen, IGF-I, IGFII and IGFBP in femur of ovariectomized rats.

\section{MATERIALS AND METHODS}

\section{Animals}

Female Wistar-strain rats ( 7 weeks old) were obtained from Charles River Japan (Kanagawa, Japan) and fed on a diet containing $200 \mathrm{~g}$ casein $/ \mathrm{kg}$ diet (200C diet, Table 1) until the operation. The rats were given the diet from 09.00 to 17.00 hours and water ad libitum. The room was kept at $22^{\circ}$ and the relative humidity at $60 \%$ with a 12 -h light (08.00-20.00 hours) and $12 \mathrm{~h}$ dark (20.00-08.00 hours) cycle. After $4 \mathrm{~d}$ the rats were either ovariectomized bilaterally or sham-operated. Then the rats were divided into two dietary groups; one was those fed on the $200 \mathrm{C}$ diet (control diet) (initial body weight: shamoperated rats, 193 (SE 2) g, $n 5$; ovariectomized rats, 189 (SE 2) g, $n$ 5) and the other was those fed on the $50 \mathrm{~g}$ casein $/ \mathrm{kg}$ diet $(50 \mathrm{C}$ diet, protein-restricted diet) (initial body weight: sham-operated rats, 186 (SE 5) g, $n$ 5; ovariectomized rats, 190 (SE 5) g, $n$ 5). The 50C diet was prepared by replacing the $150 \mathrm{~g}$ casein $/ \mathrm{kg}$ and $2.5 \mathrm{~g}$ methionine $/ \mathrm{kg}$ in the $200 \mathrm{C}$ diet by maize starch and addition of $\mathrm{CaHPO}_{4}, \mathrm{NaH}_{2} \mathrm{PO}_{4}$ and $\mathrm{Na}_{2} \mathrm{HPO}_{4}$ to adjust the contents of $\mathrm{Ca}$ and $\mathrm{P}$ in the $200 \mathrm{C}$ diet (Table 1). The feed intake of the $200 \mathrm{C}$ diet group was paired to that of the 50C diet group of the same operation, i.e. the feed intakes of the ovariectomized and sham-operated rats fed on the $50 \mathrm{C}$ diet were measured and the same amounts of the $200 \mathrm{C}$ diet were fed to the paired rats on the next day. At 3 weeks later the rats were fed at 10.00 hours and killed at 11.30 hours by decapitation under pentobarbital anaesthesia (50 $\mathrm{mg}$ pentobarbital $/ \mathrm{kg}$ body weight). The uterus was excised and weighed. Then, femurs were quickly excised and put into liquid $\mathrm{N}_{2}$. These frozen femurs were stored at $-80^{\circ}$ until the preparation of RNA. For the last $24 \mathrm{~h}$ before the rats were killed, urine samples were collected. The concentration of pyridinoline in urine was determined by an inhibition immunoassay method (Tanaka et al. 1993), based on that of Robins (1982).

\section{Total RNA preparation from bone tissues}

Total RNA was prepared from femurs according to the modified method of Chomczynski \& Sacchi (1987), Nemeth et al. (1989) and Puissant \& Houdebine (1990). After muscle and tendon were removed, cartilages at the ends of bones were further cut away from femurs in liquid $\mathrm{N}_{2}$. The bones, except the cartilages, were dissected into fine pieces with scissors, also in liquid $\mathrm{N}_{2}$. This frozen bone (we used one femur for one extraction) was put into $10 \mathrm{ml}$ solution A containing $4 \mathrm{M}$-guanidinium thiocyanate, $25 \mathrm{~mm}$-sodium citrate, $\mathrm{pH} 7 \cdot 0$, $5 \mathrm{~g}$ sarcosyl/1, 0.1 M-2-mercaptoethanol and $5 \mathrm{~g}$ antifoam $\mathrm{A} / 1$ and quickly homogenized 
with a Polytron homogenizer (Kinematica, Littau, Luzern, Switzerland). The homogenate was centrifuged at $7000 \mathrm{~g}$ for $2 \mathrm{~h}$ at $18^{\circ}$. The supernatant fraction was filtered through PTFE (pore size $0.5 \mu \mathrm{m}$, Corning, Ithaca, NY, USA). To the filtrate, $1 \mathrm{ml} 2 \mathrm{M}$-sodium acetate, $\mathrm{pH} 4.0,10 \mathrm{ml}$ phenol which had been saturated with water, and $2 \mathrm{ml}$ chloroform-isoamylalcohol $(49: 1, \mathrm{v} / \mathrm{v})$ were added and the mixture was shaken vigorously at each addition. The mixture was centrifuged at $10000 \mathrm{~g}$ for $10 \mathrm{~min}$ at $-20^{\circ}$. The water phase was saved and mixed with an equal volume of isopropanol. The mixture was kept at $4^{\circ}$ for more than $2 \mathrm{~h}$ in order to precipitate RNA. The precipitated RNA was centrifuged at $3000 \mathrm{~g}$ for $10 \mathrm{~min}$ at $4^{\circ}$. The precipitate was suspended in $2 \mathrm{ml} 4 \mathrm{M}-\mathrm{LiCl}$. The suspension was pipetted repeatedly to extract polysaccharides, then centrifuged at $3000 \mathrm{~g}$ for $10 \mathrm{~min}$ at $4^{\circ}$. The precipitate was redissolved in $500 \mu \mathrm{l}$ of a solution containing $10 \mathrm{~mm}-\mathrm{Tris}-\mathrm{HCl}$, pH 7.5, $1 \mathrm{~mm}$-EDTA, and $5 \mathrm{~g} \mathrm{SDS} / 1$. This solution was again mixed with $500 \mu \mathrm{l}$ chloroform-isoamylalcohol $(49: 1, \mathrm{v} / \mathrm{v})$ and centrifuged at $3000 \mathrm{~g}$ for $10 \mathrm{~min}$ at $4^{\circ}$. The water phase was mixed with $500 \mu 1$ isopropanol and $50 \mu 12 \mathrm{M}$-sodium acetate, pH 5.0. The precipitated RNA in the mixture was recovered by centrifugation at $15000 \mathrm{~g}$ for $10 \mathrm{~min}$ at $4^{\circ}$, dried in vacuo, and dissolved in distilled water pretreated with diethylpyrocarbonate by heating at $37^{\circ}$ for $12 \mathrm{~h}$. By determining the absorbance at 260 and $280 \mathrm{~nm}$, the purity of RNA was confirmed and the concentration of RNA in the solution was determined.

To prepare poly $(\mathrm{A})^{+}$RNA for the template of reverse transcriptase-polymerase chain reaction (RT-PCR), we purified it from total RNA using Oligotex -dT30 (Japan Roche, Tokyo, Japan) according to the manufacturer's instructions.

\section{Probes for Northern hybridization}

The probes for Northern hybridization were complementary DNA (cDNA) of rat osteopontin, rat osteocalcin, rat $\alpha 1$ type I collagen, rat IGF-I, rat IGF-II, and rat IGFBP-1 to IGFBP-6 (Table 2).

Rat osteopontin cDNA which covers the nucleotides $366-933$ of the cDNA clone reported previously (Oldberg et al. 1986) was amplified by a RT-PCR technique. The nucleotide sequence of this amplified cDNA corresponds to $\mathrm{His}^{\mathbf{}}{ }^{-}-\mathrm{His}^{285}$ of osteopontin protein. Rat osteocalcin cDNA, which covers the nucleotides 61-366 of the cDNA clone reported previously (Celeste et al. 1986), was also amplified by the RT-PCR technique. This cDNA encodes $\mathrm{Ser}^{-5}-\mathrm{Val}^{50}$, which corresponds to a part of the signal peptide and whole mature protein, and a part of the $3^{\prime}$-non-coding region of the osteocalcin gene. At first, primer oligonucleotides were synthesized with a DNA synthesizer (Applied Biosystems Model 391 PCR-MATE, Foster City, CA, USA). For rat osteopontin cDNA the sense primer was 24mer (5'-GGTACCATGCAGAGAGCGAGGATT-3') and the antisense primer was 24mer (5'-GAATTCATGGCTGTGAAACTCGTG-3'). For rat osteocalcin cDNA the sense primer was 20mer (5'-TCTCTGCTCACTCTGCTGGC-3') and the antisense primer was $21 \mathrm{mer}$ (5'-TCCAGGGCAACACATGCCCTA-3'). These nucleotides were purified by PAGE.

Using them, RT-PCR was performed as follows. In the case of rat osteopontin cDNA we prepared and cultured osteoblast cells from rat calvaria according to the method of Wong \& Cohn (1974), and total RNA was prepared from osteoblast cells in primary cultures as described previously (Miura et al. 1992). This total RNA (5 $\mu \mathrm{g}$ ) as a template was mixed with 50 pmol $3^{\prime}$-primer in $50 \mathrm{~mm}$-Tris- $\mathrm{HCl} \mathrm{pH} 8 \cdot 3,100 \mathrm{mM}-\mathrm{KCl}$ and $10 \mathrm{~mm}$ $\mathrm{MgCl}_{2}$, and heated at $78^{\circ}$ for $5 \mathrm{~min}$. The mixture was cooled to $4^{\circ}$ for $5 \mathrm{~min}$ and was mixed with $10 \mathrm{~mm}$-dithiothreitol, 2U RNase inhibitor (Takara, Kyoto, Japan), $1 \mathrm{~mm}$ each deoxynucleotide and $2 \mu 1$ of reverse transcriptase RAV-2 (Takara, Kyoto, Japan) at $42^{\circ}$ for $1 \mathrm{~h}$. The PCR reactions were performed with AmpliTaq DNA polymerase (EC 2.7.7.7; Takara, Kyoto, Japan) according to the manufacturer's instructions. First, the mixture was 
Table 1. The composition of the experimental diets $(\mathrm{g} / \mathrm{kg})$

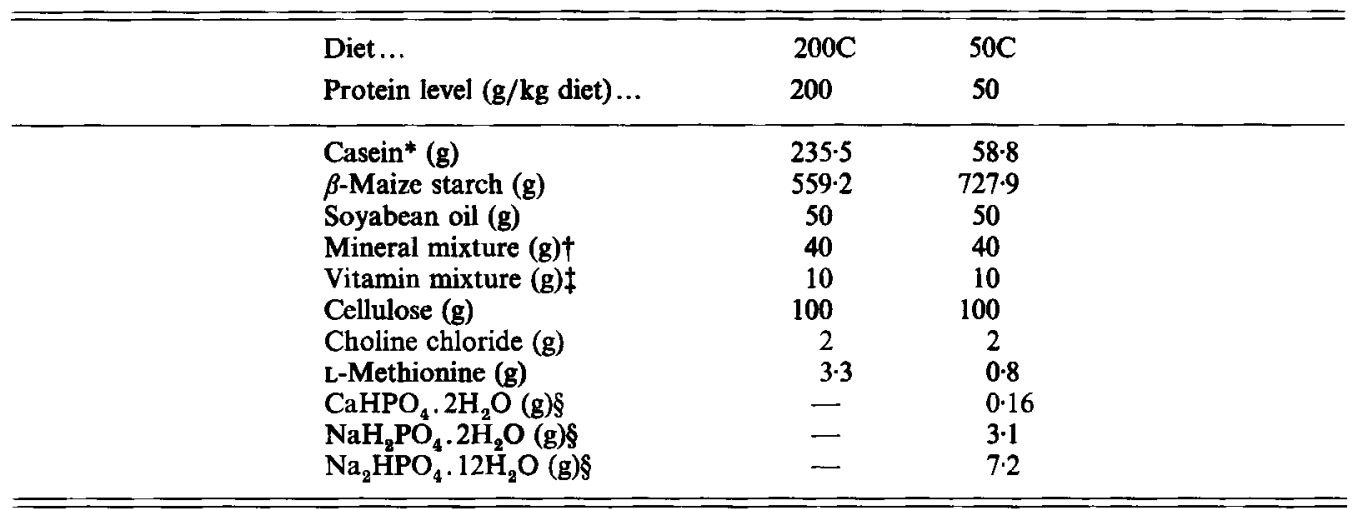

* Crude protein $850 \mathrm{~g} / \mathrm{kg}$.

$\dagger$ The mineral mixture was prepared according to the American Institute of Nutrition (1977).

† The vitamin mixture was purchased from Oriental Yeast Co., Tokyo, Japan. Its composition was (mg/ $/ \mathrm{kg})$ : retinyl acetate 172 , cholecalciferol $2 \cdot 5, \alpha$-tocopheryl acetate 5000 , menadione 5200 , thiamin hydrochloride 1200 , riboflavin 4000 , pyridoxine hydrochloride 800 , cyanocobalamin 0.5 , L-ascorbic acid 30000 , biotin 20 , pteroylmonoglutamic acid 200 , calcium pantothenate 5000 , p-amino benzoic acid 5000 , nicotinic acid 6000 , inositol 6000 , choline chloride 200000.

$\S$ To adjust the contents of $\mathrm{Ca}$ and $\mathrm{P}$ in the $50 \mathrm{C}$ diet to those in the $200 \mathrm{C}$ diet, $\mathrm{CaHPO}_{4}, \mathrm{NaH}_{2} \mathrm{PO}_{4}$ and $\mathrm{Na}_{2} \mathrm{HPO}_{4}$ were added to the $50 \mathrm{C}$ diet.

Table 2. Complementary DNA (cDNA) probes used for Northern hybridization analyses

\begin{tabular}{|c|c|c|c|}
\hline cDNA probe & $\begin{array}{l}\text { Nucleotide numbers } \\
\text { included in the probe }\end{array}$ & $\begin{array}{l}\text { Amino acid sequence } \\
\text { which the probe } \\
\text { recognizes }\end{array}$ & Reference \\
\hline Rat osteopontin & bp 366-933 & $\mathrm{His}^{97}-\mathrm{His}^{284}$ & Oldberg et al. 1986 \\
\hline Rat osteocalcin & bp $61-366$ & $\mathrm{Ser}^{-5}-\mathrm{Val}^{50}$ & Celeste et al. 1986 \\
\hline Rat $\alpha 1$ type I collagen & Pst $/$ Bam HI fragment & $\begin{array}{l}\text { Part of the triple } \\
\text { helical region }\end{array}$ & Genovese et al. 1984 \\
\hline Rat IGF-I & bp $1-738$ & $\mathrm{Met}^{-48}-\mathrm{Met}^{105}$ & Kato et al. 1990 \\
\hline Rat IGF-II & PstI fragment & $\mathrm{Arg}^{38}-\mathrm{Gln}^{156}$ & Whitfield et al. 1984 \\
\hline Rat IGFBP-1 & bp 123-848 & Pro ${ }^{11}-\mathrm{Ile}^{252}$ & Takenaka et al. 1991 \\
\hline Rat IGFBP-2 & bp 614-957 & $\mathrm{Arg}^{118}-\mathrm{His}^{231}$ & Brown et al. 1989 \\
\hline Rat IGFBP-3 & bp $451-940$ & $\mathrm{Glu}^{139}-\mathrm{Gln}^{291}$ & Takenaka et al. 1991 \\
\hline Rat IGFBP-4 & bp 502-703 & $\mathrm{Glu}^{85}-\mathrm{Glu}^{152}$ & Shimasaki et al. 1990 \\
\hline Rat IGFBP-5 & bp 558-1201 & $\mathrm{Ile}^{-17}-\mathrm{Asn}^{198}$ & Shimasaki et al. $1991 b$ \\
\hline Rat IGFBP-6 & bp $308-508$ & Pro $^{77}-$ Gly $^{142}$ & Shimasaki et al. 1991 a \\
\hline
\end{tabular}

incubated at $94^{\circ}$ for $5 \mathrm{~min}$. Then thirty cycles consisted of the denaturation step at $94^{\circ}$ for $1 \mathrm{~min}$, the annealing step at $50^{\circ}$ for $1 \mathrm{~min}$ and the extension step at $72^{\circ}$ for $2 \mathrm{~min}$. The last cycle consisted of $94^{\circ}$ for $1 \mathrm{~min}, 50^{\circ}$ for $1 \mathrm{~min}$, and $72^{\circ}$ for $10 \mathrm{~min}$. From this reaction mixture we got $576 \mathrm{bp}$ cDNA which was cloned to M13 phage vector followed by sequencing. In the case of rat osteocalcin cDNA the poly $A^{+}$RNA $(5 \mu \mathrm{g})$ prepared from rat femur as a template was used for RT-PCR as described previously. We amplified 306 bp cDNA and identified it as rat osteocalcin cDNA by sequencing.

The cDNA of rat IGF-I, rat IGFBP-1 and rat IGFBP-3 were obtained as described previously (Kato et al. 1990; Takenaka et al. 1991). Rat $\alpha 1$ type I collagen cDNA 
(Genovese et al. 1984) was kindly given by Dr H. Shikata of Meikai University (Saitama, Japan) and cDNA of rat IGF-II (Whitfield et al. 1984), rat IGFBP-2, rat IGFBP-4, rat IGFBP-5 and rat IGFBP-6 (Lemozy et al. 1994) were generously donated by Dr A. J. D'Ercole of the University of North Carolina at Chapel Hill (NC, USA).

All these probes were labelled with [ $\left.{ }^{32} \mathrm{P}\right]$ deoxycytidine triphosphate (dCTP) (111 TBq/ mmol; Amersham, Bucks.) using a Takara Random Primer DNA Labelling Kit (Takara, Kyoto, Japan) according to the manufacturer's instructions.

\section{Northern hybridization analysis}

Northern hybridization analysis was performed as described previously (Miura et al. 1992). Total RNA ( $5 \mu \mathrm{g}$ for $\alpha 1$ type I collagen mRNA, $20 \mu \mathrm{g}$ for osteocalcin and osteopontin mRNA or $40 \mu \mathrm{g}$ for IGF-I, IGF-II and each IGFBP mRNA as optimal amounts) was dissolved in $20 \mu \mathrm{l}$ of a solution containing $500 \mathrm{ml}$ deionized formamide $/ 1,30 \mathrm{ml}$ formaldehyde $/ 1,80 \mu \mathrm{g}$ ethidium bromide $/ \mathrm{ml}$ in 3-( $N$-morpholino)propanesulphonic acid (MOPS) buffer solution (Rosen et al. 1990) and heated at $55^{\circ}$ for $15 \mathrm{~min}$. The denatured RNA was quickly electrophoresed in a gel containing $15 \mathrm{~g}$ agarose/1 and $2.2 \mathrm{M}-$ formaldehyde. After electrophoresis the amount of RNA in the gel was confirmed to be equivalent by a transilluminator. The RNA in the gel was transferred to a nitrocellulose membrane and each mRNA was detected on the blot using labelled cDNA as described previously (Miura et al. 1992; Takenaka et al. 1993). Each band was quantified by a bioimaging analyser system, Fujix Bas 2000 or 3000 (Fuji Film Co., Tokyo, Japan).

\section{Statistical analysis}

The results were analysed statistically by two-way ANOVA (Snedecor \& Cochran, 1967).

\section{RESULTS}

The effects of ovariectomy and dietary protein restriction on final body weight, feed efficiency, uterus weight, fat-free dry bone weight and urinary excretion of pyridinium cross-links

Table 3 shows the body-weight changes in the groups of rats. Ovariectomized rats gained more weight than the sham-operated rats, partly because the ovariectomized rats ate more of both the $50 \mathrm{C}$ and $200 \mathrm{C}$ diets. Since each of the sham-operated or ovariectomized rats fed on the $50 \mathrm{C}$ diet was paired to one of the corresponding group fed on the $200 \mathrm{C}$ diet and the rats of the paired groups ate all the offered feed, variations in feed intake were also reproduced in the paired group. Furthermore, feed efficiency was better in ovariectomized rats than sham-operated ones. As shown in Table 3, the effect of ovariectomy was also confirmed by examination of the degenerated uterus at the time of death. Ovariectomized rats showed lower fat-free dry bone (FFDB) weight; however, there was no significant difference between the dietary groups in FFDB weight. Furthermore, ovariectomy caused an increase in pyridinoline excretion in the urine (Table 3).

\section{The effect of ovariectomy and dietary protein restriction on $m R N A$ of bone-matrix proteins in femur}

Fig. 1 and Table 4 show the effect of ovariectomy and dietary protein restriction on the amount of mRNA of osteopontin, osteocalcin and $\alpha 1$ type I collagen in femur. Neither ovariectomy nor protein restriction affected the content of mRNA of osteopontin and osteocalcin in femur. Therefore, we conclude that ovariectomy and dietary protein restriction do not affect the osteocalcin mRNA content in femur, at least under the present experimental conditions. By comparison, ovariectomy increased, and protein 
Table 3. Final body weight $(B W)$, feed intake, feed efficiency, uterus weight, fat-free dry bone weight and urinary excretion of pyridinium cross-links in ovariectomized rats fed on diets containing $200(200 \mathrm{C})$ or $50 \mathrm{~g}$ casein $/ \mathrm{kg}(50 \mathrm{C}) \dagger$

(Mean values for five rats per group with their pooled standard error)

\begin{tabular}{|c|c|c|c|c|c|c|c|}
\hline \multirow{2}{*}{$\begin{array}{l}\text { Diet... } \\
\text { Treatment... }\end{array}$} & \multicolumn{2}{|r|}{$200 \mathrm{C}$} & \multicolumn{2}{|r|}{$50 \mathrm{C}$} & \multirow[b]{2}{*}{ SEM } & \multicolumn{2}{|c|}{$\begin{array}{c}\text { Statistical significance } \\
\text { of effect of: }\end{array}$} \\
\hline & $\begin{array}{c}\text { Sham } \\
\text { operated }\end{array}$ & Ovariectomized & $\begin{array}{c}\text { Sham } \\
\text { operated }\end{array}$ & Ovariectomized & & Diet & Ovariectomy \\
\hline BW gain (g) & 49 & 75 & 40 & 60 & 5 & * & $* *$ \\
\hline Feed intake $(\mathrm{g} / \mathrm{d}) \ddagger$ & 14.9 & $17 \cdot 1$ & 14.9 & $17 \cdot 1$ & 0.6 & NS & $* *$ \\
\hline Feed efficiency§ & $17 \cdot 2$ & $23 \cdot 1$ & 14.0 & $18 \cdot 5$ & $1 \cdot 1$ & $* *$ & $* *$ \\
\hline Uterus weight (g) & 0.38 & 0.09 & 0.41 & 0.11 & 0.03 & NS & ** \\
\hline $\begin{array}{l}\text { Fat-free dry bone weight } \\
(\mathrm{mg} / \mathrm{g} \mathrm{BW})\end{array}$ & $1 \cdot 54$ & $1 \cdot 41$ & 1.56 & $1 \cdot 43$ & 0.02 & NS & $* *$ \\
\hline $\begin{array}{l}\text { Urinary excretion of } \\
\text { pyridinium cross-links } \\
\text { (mg/d) }\end{array}$ & $2 \cdot 2$ & $4 \cdot 3$ & $2 \cdot 6$ & $4 \cdot 3$ & 0.6 & NS & $* *$ \\
\hline
\end{tabular}

* $P<0.05, * * P<0.01$.

$\dagger$ For details of diets and procedures, see Table 1 and p. 812.

$\ddagger$ Daily feed intakes of the $200 \mathrm{C}$ and $50 \mathrm{C}$ groups were paired.

$\S(\mathrm{g} \mathrm{BW}$ gain $/ \mathrm{g}$ feed intake) $\times 100$.

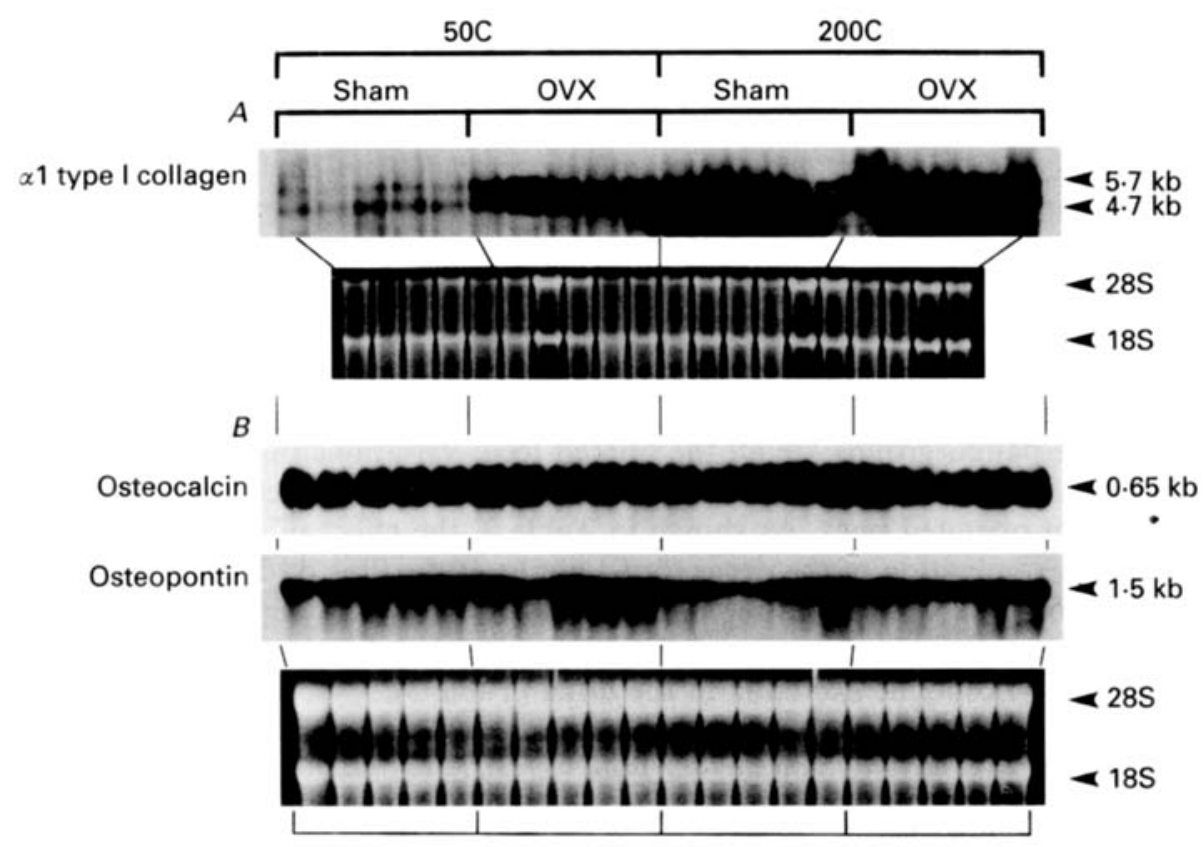

Fig. 1. Northern blot analysis of $\alpha 1$ type I collagen, osteopontin, and osteocalcin messenger RNA (mRNA) in femur from sham-operated (Sham) or ovariectomized (OVX) rats fed diets containing 200 (200C) or 50 g casein $/ \mathrm{kg}(50 \mathrm{C})$. RNA was extracted from femur of Sham or OVX rats fed on the 50C or 200C diets for 3 weeks. In the case of $\alpha 1$ type I collagen, a $5 \mu \mathrm{g}$ portion of total RNA from each rat was applied to each lane (A) and in the case of osteopontin and osteocalcin, a $20 \mu \mathrm{g}$ portion of total RNA was applied (B). The size of each mRNA is indicated on the right. Bands of ribosomal RNA stained by ethidium bromide (bottom of each figure, sizes shown on the right) demonstrate equal amounts of total RNA in each lane. 
Table 4. Effect of ovariectomy on the messenger RNA contents of bone matrix proteins in femur of rats fed on diets containing $200(200 \mathrm{C})$ or $50 \mathrm{~g}$ casein $/ \mathrm{kg}(50 \mathrm{C}) \dagger$

(The results of Northern blot hybridization analyses shown in Fig. 1 were determined quantitatively using a Fujix Bas 2000 or 3000 system (Fuji Film Co.). Values are means for five rats expressed as the relative intensity of the bands taking the mean of sham operated $200 \mathrm{C}$ group as 100 )

\begin{tabular}{|c|c|c|c|c|c|c|c|}
\hline \multirow{2}{*}{$\begin{array}{l}\text { Diet... } \\
\text { Treatment... }\end{array}$} & \multicolumn{2}{|r|}{$200 \mathrm{C}$} & \multicolumn{2}{|r|}{$50 \mathrm{C}$} & \multirow[b]{2}{*}{ SEM } & \multicolumn{2}{|c|}{$\begin{array}{c}\text { Statistical significance } \\
\text { of effect of: }\end{array}$} \\
\hline & $\begin{array}{l}\text { Sham } \\
\text { operated }\end{array}$ & Ovariectomized & $\begin{array}{c}\text { Sham } \\
\text { operated }\end{array}$ & Ovariectomized & & Diet & Ovariectomy \\
\hline Osteopontin & $100 \cdot 0$ & $143 \cdot 5$ & $149 \cdot 3$ & $132 \cdot 7$ & $14 \cdot 6$ & NS & NS \\
\hline $\begin{array}{l}\text { Osteocalcin } \\
\alpha 1 \text { Type I collagen }\end{array}$ & $100 \cdot 0$ & $96 \cdot 4$ & $111 \cdot 7$ & $117 \cdot 3$ & $13 \cdot 1$ & NS & NS \\
\hline $5.7 \mathrm{~kb}$ & $41 \cdot 0$ & 67.6 & $19 \cdot 9$ & $41 \cdot 1$ & $5 \cdot 1$ & $* *$ & $* *$ \\
\hline $4 \cdot 7 \mathrm{~kb}$ & $59-0$ & $81 \cdot 8$ & $23 \cdot 8$ & $44 \cdot 9$ & $5 \cdot 3$ & ** & ** \\
\hline Total & $100 \cdot 0$ & $149 \cdot 4$ & $43 \cdot 7$ & 86.0 & $9 \cdot 5$ & ** & ** \\
\hline
\end{tabular}

** $P<0.01$

+ For details of diets and procedures, see Table 1 and pp. 812-815.

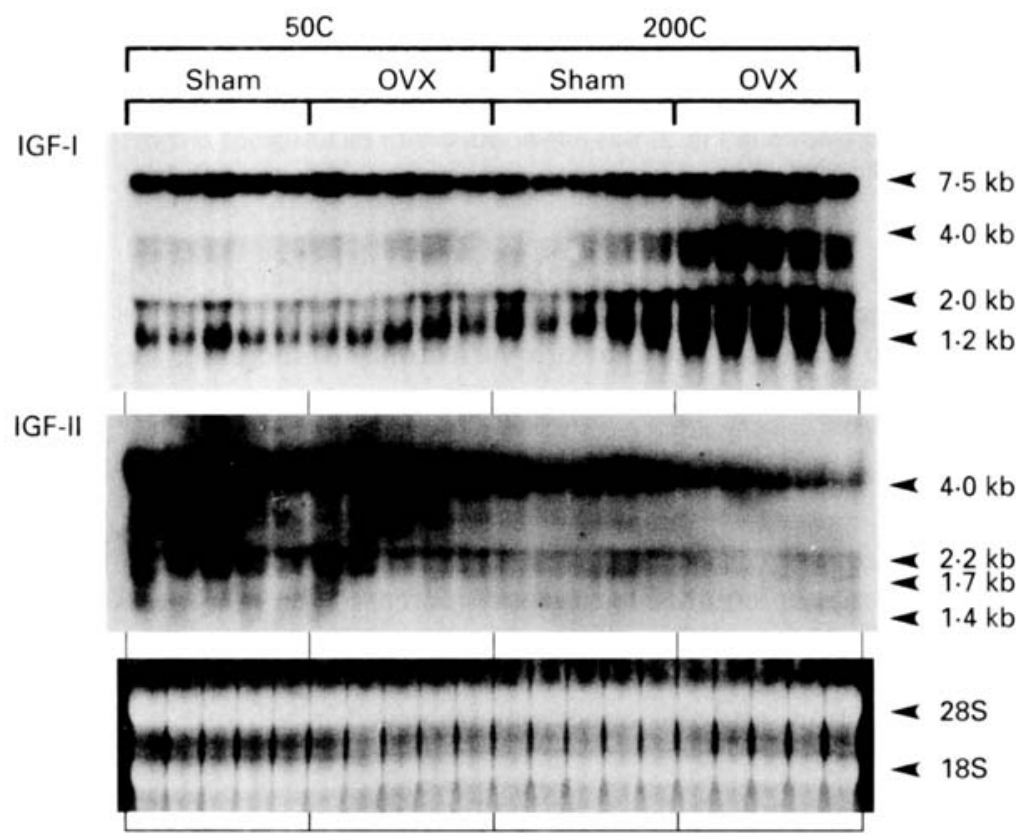

Fig. 2. Northern blot analysis of insulin-like growth factor-I (IGF-I) and IGF-II mRNA in femur from shamoperated (Sham) or ovariectomized (OVX) rats fed on diets containing 200 (200C) or $50 \mathrm{~g}$ casein/kg (50C). RNA was extracted from femur of Sham or OVX rats fed on the $50 \mathrm{C}$ or $200 \mathrm{C}$ diets for 3 weeks. A $40 \mu \mathrm{g}$ portion of total RNA from each rat was applied to each lane. The size of each mRNA is indicated on the right. Bands of ribosomal RNA stained by ethidium bromide (bottom, sizes shown on the right) demonstrate an equal amount of total RNA in each lane. 


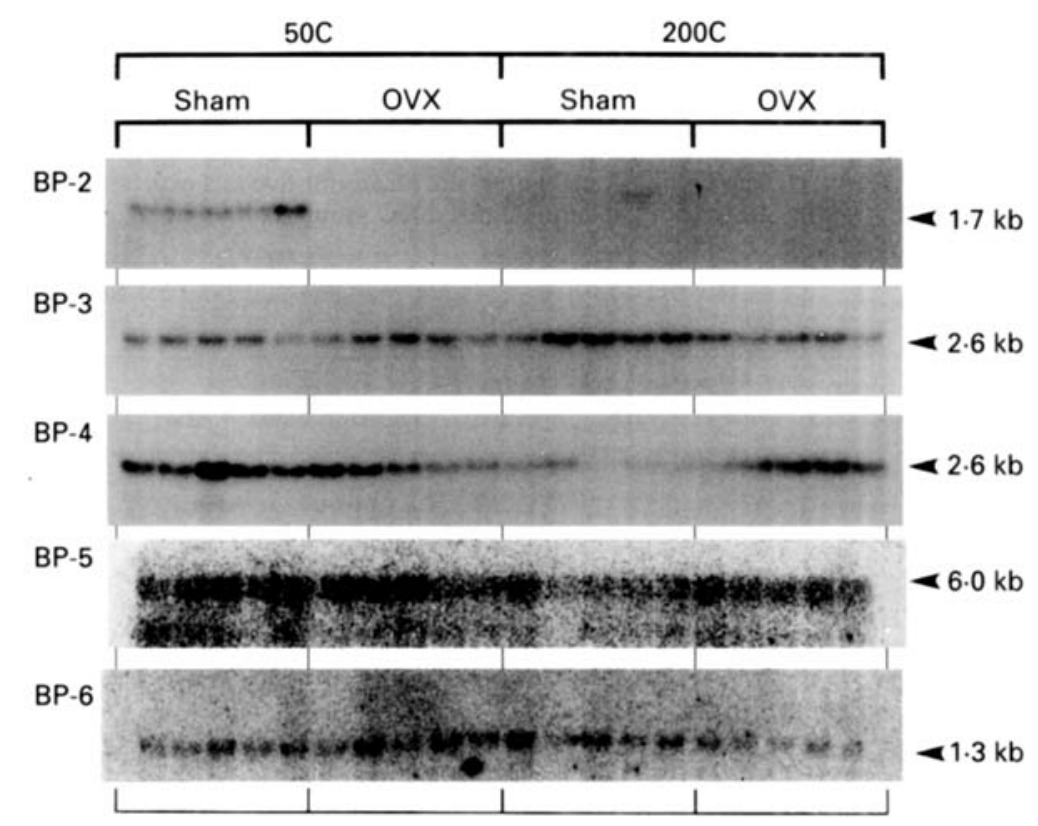

Fig. 3. Northern blot analysis of insulin-like growth factor-binding protein-2 (IGFBP-2), IGFBP-3, IGFBP-4, IGFBP-5, and IGFBP-6 messenger RNA (mRNA) in femur from sham-operated (Sham) or ovariectomized $(\mathrm{OVX})$ rats fed on diets containing $200(200 \mathrm{C})$ or $50 \mathrm{~g}$ casein $/ \mathrm{kg}(50 \mathrm{C})$. The membrane prepared for analysis of IGF-I and IGF-II mRNA (shown in Fig. 2) was rehybridized with each labelled IGFBP probe. The size of each mRNA is indicated on the right.

restriction decreased, $\alpha 1$ type I collagen mRNA content in femur. Because the interaction of these two treatments was not statistically significant, we conclude that the effect of protein restriction to decrease, and that of ovariectomy to increase, the $\alpha 1$ type I collagen mRNA content are independent.

The effect of ovariectomy and dietary protein restriction on $m R N A$ of insulin-like growth factors in femur

Fig. 2 shows the effects of ovariectomy and dietary protein restriction on the IGF-I and IGF-II mRNA contents in femur. Ovariectomy increased the IGF-I mRNA content in the rats fed on the $200 \mathrm{C}$ diet, and this effect was most noticeable in the $4.0,2.0$ and $1.2 \mathrm{~kb}$ species. Conversely IGF-II mRNA content was decreased by ovariectomy and increased by dietary protein restriction, and this effect was observed in all four of the IGF-II mRNA species.

The effects of ovariectomy and dietary protein restriction on $m R N A$ of insulin-like growth factor-binding proteins in femur

IGFBP-1 mRNA was not detected in femur even in the protein-restricted and ovariectomized rats (results not shown). Fig. 3 and Table 5 show the effects of ovariectomy and protein restriction on femur IGFBP-2, IGFBP-3, IGFBP-4, IGFBP-5 and IGFBP-6 mRNA contents. Protein restriction increased the IGFBP-2 mRNA content and ovariectomy reduced it considerably in both diet groups. As for the IGFBP-3 mRNA, its content was significantly reduced by protein restriction. Conversely, IGFBP-4 and IGFBP5 mRNA contents in femur increased during protein restriction. IGFBP-6 mRNA in the 
Table 5. Effect of ovariectomy on the messenger RNA contents of insulin-like growth factor-binding proteins (IGFBP) in femur of rats fed on diets containing $200(200 \mathrm{C})$ or $50 \mathrm{~g}$ casein $/ \mathrm{kg}(50 \mathrm{C}) \dagger$

(The results of Northern blot hybridization analyses shown in Fig. 3 were determined quantitatively using a Fujix Bas 2000 or 3000 system (Fuji Film Co.). Values are means for five rats expressed as the relative intensity of the bands taking the mean of sham operated $200 \mathrm{C}$ group as 100 )

\begin{tabular}{|c|c|c|c|c|c|c|c|c|}
\hline \multirow{2}{*}{$\begin{array}{l}\text { Diet... } \\
\text { Treatment ... }\end{array}$} & \multicolumn{2}{|r|}{$200 \mathrm{C}$} & \multicolumn{2}{|r|}{$50 \mathrm{C}$} & \multicolumn{4}{|c|}{$\begin{array}{l}\text { Statistical significance } \\
\text { of effect of: }\end{array}$} \\
\hline & $\begin{array}{c}\text { Sham } \\
\text { operated }\end{array}$ & Ovariectomized & $\begin{array}{c}\text { Sham } \\
\text { operated }\end{array}$ & Ovariectomized & SEM & $\begin{array}{l}\text { Diet } \\
\text { (D) }\end{array}$ & $\begin{array}{c}\text { Ovariectomy } \\
\text { (O) }\end{array}$ & $\mathbf{O} \times \mathbf{D}$ \\
\hline IGFBP-2 & $100 \cdot 0$ & $54-7$ & $273 \cdot 3$ & $19 \cdot 0$ & $16 \cdot 7$ & $* *$ & $* *$ & ** \\
\hline IGFBP-3 & $100 \cdot 0$ & $87 \cdot 2$ & $69 \cdot 8$ & $70 \cdot 7$ & $6 \cdot 2$ & ** & NS & NS \\
\hline IGFBP-4 & $100 \cdot 0$ & $223 \cdot 8$ & $270 \cdot 1$ & $185 \cdot 4$ & $26 \cdot 1$ & $*$ & NS & $* *$ \\
\hline IGFBP-5 & $100 \cdot 0$ & $125 \cdot 4$ & 157.9 & $146 \cdot 3$ & $10 \cdot 8$ & $* *$ & NS & NS \\
\hline IGFBP-6 & $100 \cdot 0$ & $64 \cdot 7$ & $101 \cdot 1$ & $119 \cdot 7$ & $12 \cdot 6$ & $*$ & NS & $*$ \\
\hline
\end{tabular}

* $P<0.05$, ** $P<0.01$.

$\dagger$ For details of diets and procedures, see Table 1 and pp. 812-815.

femur was also increased by protein restriction and furthermore ovariectomy significantly decreased its content in the rats fed on the control diet.

\section{DISCUSSION}

As shown in Table 3, the effect of ovariectomy was confirmed by examination of the degenerated uterus and lower FFDB weight at the time of death; however, there was no significant difference between the dietary groups in FFDB weight. The fact that ovariectomy also increased excretion of pyridinium cross-links in the urine (Table 3) suggested that the decrease in bone mass in ovariectomized rats was caused by accelerated turnover of bone metabolism through lack of ovarian oestrogens. In these rats, ovariectomy and protein restriction clearly affected the mRNA content of the bone-matrix protein for $\alpha 1$ type I collagen and IGF, which have been presumed to play important roles in bone formation.

In the present study we developed a modified method to extract the total RNA from the homogenate of femurs by slight modification of the method of Chomczynski \& Sacchi (1987), Nemeth et al. (1989) and Puissant \& Houdebine (1990). This modification involved extraction of the total RNA from whole femurs except the cartilages at the end of the bones, described on pp. 812-813. Since we removed the epiphyseal growth plate where active bone formation is observed in growing rats, we believe that our results reflect changes in the whole bone, showing primarily the activity of trabecular bone turnover. Turner et al. (1990) reported that a treatment with diethylstilboestrol decreased the contents of mRNA of $\alpha 1$ type I collagen, osteopontin and osteocalcin in the periosteal cells obtained from femur of ovariectomized rats by collagenase (EC 3.4.24.3) digestion. Westerlind et al. (1993) reported similar results in the cancellous bone of ovariectomized rats and recently showed that ovariectomy increased $\alpha 1$ type I collagen and osteocalcin mRNA in bone (Westerlind et al. 1994). Our present results are consistent with their observations in the case of $\alpha 1$ type I collagen and further show the effect of dietary protein restriction on the changes in mRNA of these bone-matrix proteins. In particular, the observations that both ovariectomy and protein restriction affected the mRNA contents of the proteins produced by osteoblasts could be very important. 
IGF-I mRNA was increased by ovariectomy only in the high-protein group. Ovariectomy also increased $\alpha 1$ type I collagen mRNA, despite the fact that it also reduced FFDB weight, whilst dietary protein restriction decreased the $\alpha 1$ type I collagen mRNA. These apparently conflicting changes could possibly be explained by the following hypothesis. Following ovariectomy, osteoclast activity and bone resorption are enhanced. At the same time, osteoblast activity and bone formation are enhanced (Wronski et al. 1988a). Gain or loss of bone tissue is the result of the balance between these two processes. This activation of osteoblasts could be the compensatory effect of the enhanced bone resorption. Collagen $\alpha 1$ type I has been shown to be synthesized in bone primarily by osteoblasts (Sandberg \& Vuorio, 1987; Sandberg et al. 1988, 1989). Therefore, the increase in $\alpha$ l type I collagen mRNA is well explained by the increased activity of osteoblasts.

The activity of osteoblasts, including the possibly enhanced differentiation of progenitor cells to osteoblasts, has been shown to be regulated by many factors (Baylink et al. 1993; Canalis et al. 1993). IGF-I is thought to be one of these factors which can regulate the activity of osteoblasts to stimulate their proliferation and the synthesis of bone proteins (Canalis, 1980; McCarthy et al. 1989; Thiebaud et al. 1990). Also, many researchers have reported that IGF are produced locally in bone tissues (Stracke et al. 1984; Canalis et al. 1988 ) and that their production is regulated by oestrogens (Ernst et al. 1989; Gray et al. 1989). These observations are possibly inconsistent with our results that ovariectomy increased the content of IGF-I mRNA in femur. Therefore, the increase in IGF-I mRNA by ovariectomy may mean the involvement of this hormone in the compensatory activity of bone resorption by stimulation of osteoblasts. If this is the case, IGF-I produced in bone probably works on the bone tissue itself in an autocrine or paracrine fashion. The fact that the increase in IGF-I mRNA is only observed in well-fed rats may mean that the compensatory activation of osteoblasts is impaired in protein-restricted rats. We and others have shown that quantity and quality of dietary proteins affect the plasma IGF-I concentration and content of IGF-I mRNA in rat liver (Prewitt et al. 1982; Straus \& Takemoto, 1990; Takahashi et al. 1990; Miura et al. 1992). So the content of IGF-I mRNA in femur could be controlled by a similar mechanism to that in liver in response to dietary proteins.

Unlike the case of IGF-I, the femur mRNA content of IGF-II decreased in the ovariectomized rats, but clearly increased in the protein-restricted rats; however, the physiological significance of the increase in IGF-II mRNA in bone under protein restriction and the decrease in ovariectomy remain to be elucidated.

Messenger RNA of IGFBP-2, IGFBP-3, IGFBP-4, IGFBP-5 and IGFBP-6 were found in femur in the present study. Our results confirm the previous observations that rat osteoblasts express these five IGFBP (Schmid et al. 1992; Birnbaum \& Wiren, 1994). The content of each IGFBP mRNA in femur was regulated by protein restriction and ovariectomy in different ways, as we showed here. We and others have reported that plasma concentration and mRNA content in liver of each IGFBP are also differently regulated (Donovan et al. 1991; Thissen et al. 1991; Umezawa et al. 1991; Takenaka et al. 1993). However, the effects of protein restriction and ovariectomy on the contents of these IGFBP in femur were different from those on the mRNA contents of these IGFBP in liver which we will report in a following paper (Y. Higashi, A. Takenaka, S.-I. Takahashi and T. Noguchi, unpublished results). Notably, an increase in IGFBP-2 mRNA under protein restriction was not observed in the femur of ovariectomized rats. This may mean that IGFBP-2 gene expression is mainly regulated by oestrogens in femur. In the case of IGFBP4, mRNA content responded to protein restriction in femur, but not in liver. At present, we do not have any information concerning the oestrogen response elements in the genes of any IGFBP except IGFBP-6 (Zhu et al. 1993). The reason for the different response 
between the tissues is not explained yet; however, the distinctive regulation of IGFBP in femur could be important in controlling bone formation. As described previously, IGFBP have been shown to inhibit or enhance IGF's action in cell-specific ways. In osteoblast cultures it has been reported that IGFBP-1, IGFBP-2, IGFBP-3 and IGFBP-4 inhibit IGF's action and IGFBP-5 stimulates the activity of IGF (Mohan et al. 1989; Campbell \& Novak, 1991; Feyen et al. 1991; Andreas \& Birnbaum, 1992). Furthermore, the role of IGFBP-6 is not clear. Taken together, regulated production of IGFBP in response to oestrogens or protein restriction in femur could affect the availability of IGF and as a result, bone formation could be controlled through modulated IGF activities.

In summary, the present results show that both ovariectomy and protein restriction can affect the mRNA contents, in femur, of some proteins which have been presumed to be important physiologically in bone formation. The results suggest that protein restriction after menopause should be carefully avoided, because it may depress the activity of bone formation by osteoblasts.

The authors express their great appreciation to Dr H. Shikata of Meikai University (Saitama, Japan) for providing rat $\alpha 1$ type I collagen cDNA and to Dr A. J. D'Ercole in the University of North Carolina (NC, USA) for donating cDNA of rat IGF-II, rat IGFBP-2, rat IGFBP-4, rat IGFBP-5 and rat IGFBP-6. They also thank Dr D. Fujimoto and Mr H. Tanaka (Tokyo University of Agriculture and Technology, Tokyo, Japan) for measuring the concentration of pyridinoline in the urine.

\section{REFERENCES}

American Institute of Nutrition (1977). Report of the American Institute of Nutrition ad hoc committee on standards for nutritional studies. Journal of Nutrition 107, 1340-1348.

Andreas, D. L. \& Birnbaum, R. S. (1992). Human osteoblast-derived insulin-like growth factor (IGF) binding protein-5 stimulates osteoblast mitogenesis and potentiates IGF action. Journal of Biological Chemistry 267, 22467-22472.

Baylink, D. J., Finkelman, R. D. \& Mohan, S. (1993). Growth factors to stimulate bone formation. Journal of Bone and Mineral Research 8, S565-S572.

Birnbaum, R. S. \& Wiren, K. M. (1994). Changes in insulin-like growth factor-binding protein expression and secretion during the proliferation, differentiation, and mineralization of primary cultures of rat osteoblasts. Endocrinology 135, 223-230.

Brown, A. L., Chiarotti, L. \& Orlowski, C. C. (1989). Nucleotide sequence and expression of a cDNA clone encoding a fetal rat binding protein for insulin-like growth factors. Journal of Biological Chemistry 264, 5148-5154.

Campbell, P. G. \& Novak, J. F. (1991). Insulin-like growth factor binding protein (IGFBP) inhibits IGF action on human osteosarcoma cells. Journal of Cellular Physiology 149, 293-300.

Canalis, E. (1980). Effect of insulin-like growth factor I on DNA and protein synthesis in cultured rat calvaria. Journal of Clinical Investigation 66, 709-719.

Canalis, E., McCarthy, T. \& Centrella, M. (1988). Isolation and characterization of insulin-like growth factor I (somatomedin-C) from cultures of fetal rat calvariae. Endocrinology 122, 22-27.

Canalis, E., Pash, J. \& Varghese, S. (1993). Skeletal growth factors. Critical Reviews in Eukaryotic Gene Expression 3, 155-166.

Celeste, A. J., Rosen, V., Buecker, J. L., Wang, E. A. \& Wozney, J. M. (1986). Isolation of the human gene for bone gla protein utilizing mouse and rat cDNA clones. EMBO Journal 5, 1885-1890.

Chomczynski, P. \& Sacchi, N. (1987). Single-step method of RNA isolation by acid guanidium thiocyanatephenol-chloroform extraction. Analytical Biochemistry 162, 156-159.

Christiansen, C., Christiansen, M. S., Larsen, N. E. \& Transbol, I. B. (1982). Pathophysiological mechanisms of estrogen effect on bone metabolism. Dose-response relationships in early postmenopausal women. Journal of Clinical Endocrinology and Metabolism 55, 1124-1130.

Donovan, S. M., Atilano, L. C., Hintz, R. L., Wilson, D. M. \& Rosenfeld, R. G. (1991). Differential regulation of the insulin-like growth factors (IGF-I and -II) and IGF binding proteins during malnutrition in the neonatal rat. Endocrinology 129, 149-157.

Ernst, M., Heath, J. K. \& Rodan, G. (1989). Estradiol effects on proliferation, messenger ribonucleic acid for collagen and insulin-like growth factor-I, and parathyroid hormone-stimulated adenylate cyclase activity in osteoblastic cells from calvariae and long bones. Endocrinology 125, 825-833. 
Feyen, J. H. M., Evans, D. B., Binkert, C., Heinlich, G. F., Geisse, S. \& Kocher, H. P. (1991). Recombinant human [Cys281] insulin-like growth factor-binding protein 2 inhibits both basal and insulin-like growth factor I-stimulated proliferation and collagen synthesis in fetal rat calvariae. Journal of Biological Chemistry 266, 19469-19474.

Gallagher, J. C. (1990). The pathogenesis of osteoporosis. Bone and Mineral 9, 215-227.

Genovese, C., Rowe, D. \& Kream, B. (1984). Construction of DNA sequences complementary to rat $\alpha_{1}$ and $\alpha_{2}$ collagen mRNA and their use in studying the regulation of type I collagen synthesis by 1,25-dihydroxyvitamin D. Biochemistry 23, 6201-6216.

Gray, T. K., Mohan, S., Linkhart, T. A. \& Baylink, D. J. (1989). Estradiol stimulates in vitro the secretion of insulin-like growth factors by the clonal osteoblastic cell line, UMR-106. Biochemical and Biophysical Research Communications 158, 407-412.

Horowitz, M. C. (1993). Cytokines and estrogen in bone: anti-osteoporotic effects. Science 260, 626-627.

Ismail, F., Epstein, S., Fallon, M. D., Thomas, S. B. \& Reinhardt, T. A. (1988). Serum bone gla protein and the vitamin D endocrine system in the oophorectomized rat. Endocrinology 122, 624-630.

Kalu, D. N. (1991). The ovariectomized rat model of postmenopausal bone loss. Bone and Mineral 15, $175-192$.

Kalu, D. N., Liu, C. C., Hardin, R. R. \& Hollis, B. W. (1989). The aged rat model of ovarian hormone deficiency bone loss. Endocrinology 124, 7-16.

Kalu, D. N., Liu, C. C., Salerno, E., Hollis, B., Echon, R. \& Ray, M. (1991). Skeletal response of ovariectomized rats to low and high doses of 17 $\beta$-estradiol. Bone and Mineral 14, 175-187.

Kato, H., Takenaka, A., Miura, Y., Nishiyama, M. \& Noguchi, T. (1990). Evidence of introduction by molecular cloning of artificial inverted sequence at the $5^{\prime}$ terminus of the sense strand of rat insulin-like growth factor-I cDNA. Agricultural and Biological Chemistry 54, 2225-2230.

Lemozy, S., Pucilowska, J. B. \& Underwood, L. E. (1994). Reduction of insulin-like growth factor-I (IGF-I) in protein restricted rats is associated with differential regulation of IGF-binding protein messenger ribonucleic acids in liver and kidney, and peptides in liver and serum. Endocrinology 135, 617-623.

LeRoith, D. \& Pimstone, B. L. (1973). Bone metabolism and comparison in the protein-deprived rat. Clinical Science 44, 305-319.

McCarthy, T. L., Centrella, M. \& Canalis, E. (1989). Regulatory effects of insulin-like growth factors I and II on bone collagen synthesis in rat calvarial cultures. Endocrinology 124, 301-309.

Manolagas, S. C. \& Jilka, R. L. (1992). Cytokines, hematopoiesis, osteoclastogenesis, and estrogens. Calcified Tissue International 50, 199-202.

Miura, Y., Kato, H. \& Noguchi, T. (1992). Effects of dietary proteins on insulin-like growth factor-1 (IGF-1) messenger ribonucleic acid content in rat liver. British Journal of Nutrition 67, 257-265.

Mohan, S., Bautista, C. M., Wergedal, J. \& Baylink, D. J. (1989). Isolation of an inhibitory insulin-like growth factor (IGF) binding protein from bone cell-conditioned medium: a potential local regulator of IGF action. Proceedings of the National Academy of Sciences USA 86, 8338-8342.

Nemeth, G. G., Heydemann, A. \& Bolander, M. E. (1989). Isolation and analysis of ribonucleic acids from skeletal tissues. Analytical Biochemistry 183, 301-304.

Nilsson, A., Ohlsson, C., Isaksson, O. G. P., Lindahl, A. \& Isgaard, J. (1994). Hormonal regulation of longitudinal bone growth. European Journal of Clinical Nutrition 48, S150-S160.

Oldberg, A., Franzen, A. \& Heinegard, D. (1986). Cloning and sequence analysis of rat bone sialoprotein (osteopontin) cDNA reveals an Arg-Gly-Asp cell-binding sequence. Proceedings of the National Academy of Sciences USA 83, 8819-8823.

Prewitt, T. E., D'Ercole, A. J., Switzer, B. R. \& Van Wyk, J. J. (1982). Relationship of serum immunoreactive somatomedin-C to dietary protein and energy in growing rats. Journal of Nutrition 112, 144-150.

Puissant, C. \& Houdebine, L. M. (1990). An improvement of the single-step method of RNA isolation by acid guanidinium thiocyanate-phenol-chloroform extraction. BioTechniques 8, 148-149.

Robins, S. P. (1982). An enzyme-linked immunoassay for the collagen cross-link pyridinoline. Biochemical Journal 207, 617-620.

Rosen, C. J., Donahue, L. R. \& Hunter, S. J. (1994). Insulin-like growth factors and bone: the osteoporosis connection. Proceedings of the Society for Experimental Biology and Medicine 206, 83-102.

Rosen, K. M., Lamperti, E. D. \& Villa-Komaroff, L. (1990). Optimizing the Northern blot procedure. BioTechniques 8, 398-403.

Sandberg, M., Autio-Harmainen, H. \& Vuorio, E. (1988). Localization of the expression of types I, III, and IV collagen, TGF- $\beta 1$ and c-fos genes in developing human calvarial bones. Developmental Biology 130, 324-334.

Sandberg, M., Tamminen, M., Hirvonen, H., Vuorio, E. \& Pihlajaniemi, T. (1989). Expression of mRNAs coding for the al chain of type XIII collagen in human fetal tissues: comparison with expression of mRNAs for collagen types I, II, and III. Journal of Cell Biology 109, 1371-1379.

Sandberg, M. \& Vuorio, E. (1987). Localization of types I, II, and III collagen mRNAs in developing human skeletal tissues by in situ hybridization. Journal of Cell Biology 104, 1077-1084.

Schmid, C., Schlapfer, I., Futo, E., Waldvogel, M., Schwander, J., Zapf, J. \& Froesch, E. R. (1992). Triiodothyronine (T3) stimulates insulin-like growth factor (IGF)-1 and IGF binding protein (IGFBP)-2 production by rat osteoblasts in vitro. Acta Endocrinologica 126, 467-473.

Shimasaki, S., Gao, L., Shimonaka, M. \& Ling, N. (1991 a). Isolation and molecular cloning of insulin-like growth factor-binding protein-6. Molecular Endocrinology 5, 938-948. 
Shimasaki, S., Shimonaka, M., Zhang, H.-P. \& Ling, N. (1991 b). Identification of five different insulin-like growth factor binding-proteins (IGFBPs) from adult rat serum and molecular cloning of a novel IGFBP-5 in rat plasma. Journal of Biological Chemistry 266, 10646-10653.

Shimasaki, S., Uchiyama, F., Shimonaka, M. \& Ling, N. (1990). Molecular cloning of the cDNAs encoding a novel insulin-like growth factor binding protein from rat and human. Molecular Endocrinology 4, 1451-1458.

Snedecor, G. W. \& Cochran, W. G. (1967). One-way classifications. Analysis of variance. Inspection of all differences between pairs of means. In Statistical Methods, 6th ed., pp. 271-273. Ames, Iowa: Iowa State University Press.

Stracke, H., Schulz, A., Moeller, D., Rossol, S. \& Schatz, H. (1984). Effect of growth hormone on osteoblasts and demonstration of somatomedin-C/IGF-I in bone organ culture. Acta Endocrinologica 107, 16-24.

Straus, D. S. \& Takemoto, C. D. (1990). Effect of dietary protein deprivation on insulin-like growth factor (IGF)I and -II, IGF binding protein-2, and serum albumin gene expression in rat. Endocrinology 127, 1849-1860.

Takahashi, S., Kajikawa, M., Umezawa, T., Takahashi, S.-I., Kato, H., Miura, Y., Nam, T. J., Noguchi, T. \& Naito, H. (1990). Effect of dietary proteins on the plasma immunoreactive insulin-like growth factor1/somatomedin C concentration in the rat. British Journal of Nutrition 63, 521-534.

Takenaka, A., Hirosawa, M., Mori, M., Yamada, S., Miura, Y., Kato, H., Takahashi, S.-I. \& Noguchi, T. (1993). Effect of protein nutrition on the mRNA content of insulin-like growth factor-binding protein-1 in liver and kidney of rats. British Journal of Nutrition 69, 73-82.

Takenaka, A., Miura, Y., Mori, M., Hirosawa, M., Kato, H. \& Noguchi, T. (1991). Distribution of messenger RNAs of insulin-like growth factor (IGF)-binding proteins-1 and -3 between parenchymal and nonparenchymal cells in rat liver. Agricultural and Biological Chemistry 55, 1191-1193.

Tanaka, H., Hirayama, N., Tachikawa, H., Fujimoto, D., Nokokuma, S. \& Hasegawa, M. (1993). Measurement of pyridinium cross-links by enzyme-linked immunoassay. Seikagaku 65, 798.

Thiebaud, D., Whang, K., Findlay, D. M., Harker, M. \& Martin, T. J. (1990). Insulin-like growth factor I regulates mRNA levels of osteonectin and pro- $\alpha 1(1)$-collagen in clonal preosteoblastic calvarial cells. Journal of Bone and Mineral Research 5, 761-767.

Thissen, J.-P., Underwood, L. E., Maiter, D., Maes, M., Clemmons, D. R. \& Ketelslegers, J.-M. (1991). Failure of insulin-like growth factor-I (IGF-I) infusion to promote growth in protein-restricted rats despite normalization of serum IGF-I concentrations. Endocrinology 128, 885-890.

Turner, R. T., Colvard, D. S. \& Spelsberg, T. C. (1990). Estrogen inhibition of periosteal bone formation in rat long bones: down-regulation of gene expression for bone matrix proteins. Endocrinology 127, 1346-1351.

Umezawa, T., Ohsawa, Y., Miura, Y., Kato, H. \& Noguchi, T. (1991). Effect of protein deprivation on insulinlike growth factor-binding proteins in rats. British Journal of Nutrition 66, 105-116.

Westerlind, K. C., Wakley, G. K., Evans, G. L. \& Turner, R. T. (1993). Estrogen does not increase bone formation in growing rats. Endocrinology 133, 2924-2934.

Westerlind, K. C., Wronski, T. J., Evans, G. L. \& Turner, R. T. (1994). The effect of long-term ovarian hormone deficiency on transforming growth factor- $\beta$ and bone matrix protein mRNA expression in rat femora. Biochemical and Biophysical Research Communications 200, 283-289.

Whitfield, H. J., Bruni, C. B., Frunzio, R., Terrell, J. E., Nissley, S. P. \& Rechler, M. M. (1984). Isolation of a cDNA clone encoding rat insulin-like growth factor-II precursor. Nature 312, 277-280.

Wong, G. L. \& Cohn, D. W. (1974). Separation of parathyroid hormone and calcitonin-sensitive cells from nonresponsive bone cells. Nature 252, 713-715.

Wronski, T. J., Cintron, M. \& Dann, L. M. (1988a). Temporal relationship between bone loss and increased bone turnover in ovariectomized rats. Calcified Tissue International 43, 179-183.

Wronski, T. J., Cintron, M., Doherty, A. L. \& Dann, L. M. (1988b). Estrogen treatment prevents osteopenia and depresses bone turnover in ovariectomized rats. Endocrinology 123, 681-686.

Wronski, T. J., Lowry, P. L., Walsh, C. C. \& Ignaszewski, L. A. (1985). Skeletal alterations in ovariectomized rats. Calcified Tissue International 37, 324-328.

Wronski, T. J., Walsh, C. C. \& Ignaszewski, L. A. (1986). Histologic evidence for osteopenia and increased bone turnover in ovariectomized rats. Bone 7, 119-123.

Zhu, X., Ling, N. \& Shimasaki, S. (1993). Structural characterization of the rat insulin-like growth factor binding protein-6 gene. Biochemical and Biophysical Research Communications 191, 1237-1243. 